\title{
Identification of Macrolide Antibiotic-binding Human_p8 Protein
}

\author{
Tetsuro Morimura, Mio Hashiba, Hiroshi Kameda, Mihoko Takami, \\ Hirokazu Takahama, Masahiko Ohshige, Fumio Sugawara
}

Received: December 10, 2007 / Accepted: May 1, 2008

(C) Japan Antibiotics Research Association

\begin{abstract}
Clarithromycin is a macrolide antibiotic that is widely used in clinical medicine. Macrolide antibiotics such as clarithromycin specifically bind to the $50 \mathrm{~S}$ subunit of the bacterial ribosome thereby interfering with protein biosynthesis. A selected peptide sequence from our former study, composed of 19 amino acids, which was isolated from a phage display library because of its ability to bind clarithromycin, displayed significant similarity to a portion of the human_p8 protein. The recombinant p8 protein binds to biotinylated-clarithromycin immobilized on a streptavidin-coated sensor chip and the dissociation constant was determined. The binding of recombinant $\mathrm{p} 8$ protein to double-stranded DNA was inhibited by biotinylated-clarithromycin, clarithromycin, erythromycin and azithromycin in gel mobility shift assay. Dechlorogriseofulvin, obtained from a natural product screening, also inhibited human $\mathrm{p} 8$ protein binding to DNA. This study illustrates the general utility of the phage display method in detecting protein-ligand interactions.
\end{abstract}

Keywords macrolide antibiotics, clarithromycin, p8 protein, phage display

F. Sugawara (Corresponding author), T. Morimura, M. Hashiba, H. Kameda, M. Takami, H. Takahama, M. Ohshige: Genome and Drug Discovery Research Center, Department of Applied Biological Science, Tokyo University of Science, 2641 Yamazaki, Noda, Chiba 278-8510, Japan,

E-mail: sugawara@rs.noda.tus.ac.jp

\section{Introduction}

Launched in 1990 by Abbott Laboratories, clarithromycin A (CLA: synonym of 6-O-methylerythromycin, 1) [1] is a macrolide antibiotic that is commonly used to treat a variety of human bacterial infections. Macrolide antibiotics, represented by erythromycin A (ERY, 2) and its structural homologues, specifically bind to the bacterial $50 \mathrm{~S}$ ribosomal subunit resulting in the inhibition of bacterial protein biosynthesis [2]. CLA (1) is also commonly used to target gastric Helicobacter pylori, which is implicated in both gastric ulcers and cancer [3]. Numerous studies to develop novel pharmaceutical applications for macrolide antibiotics, including CLA (1), ERY (2) and azithromycin (AZM, 3), have been published [4]. Examples of these applications include increasing IL8 secretion from human leukocytes [5, 6], modulating growth factor-induced expression of heparanase mRNA in human lung cancer cells in vitro [7] and suppressing angiogenesis and tumor growth in vivo [8]. Although there is good evidence that human cells or even cancers respond to macrolide antibiotics [9], the identity of human macrolide antibiotic-binding proteins is unknown.

To identify CLA-binding protein, we used two T7 phage libraries composed of cDNA fragments from human leukocyte and Drosophila melanogaster exhibiting random peptides on the facial capsid protein [10]. A phage clone expressing peptide, NSPAGISRELVDKLAAALE, was selectively amplified after biopanning with a biotinylated derivative of CLA (6). Using this technique we have identified the clarithromycin-binding human_p8 protein. Furthermore, interaction between the recombinant $\mathrm{p} 8$ protein and CLA (1), ERY (2) or AZM (3) interferes with 


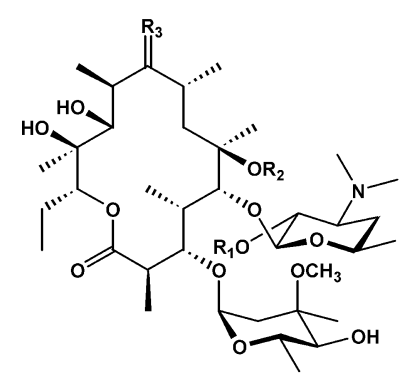

1: $\mathrm{R}_{1}=\mathrm{H}, \mathrm{R}_{2}=\mathrm{Me}, \mathrm{R}_{3}=\mathrm{O}$

2: $\mathrm{R}_{1}=\mathrm{H}, \mathrm{R}_{2}=\mathrm{H}, \quad \mathrm{R}_{3}=\mathrm{O}$

5: $\mathrm{R}_{1}=\mathrm{H}, \mathrm{R}_{2}=\mathrm{H}, \quad \mathrm{R}_{3}=\mathrm{NOCH}_{2} \mathrm{OCH}_{2} \mathrm{CH}_{2} \mathrm{OCH}_{3}$

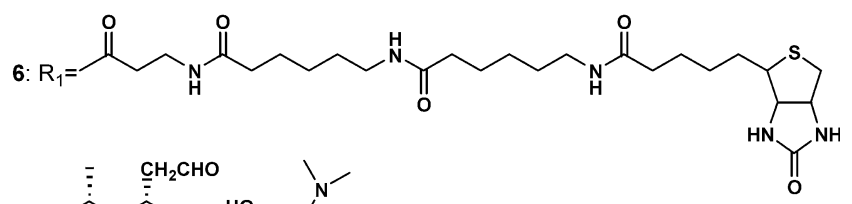

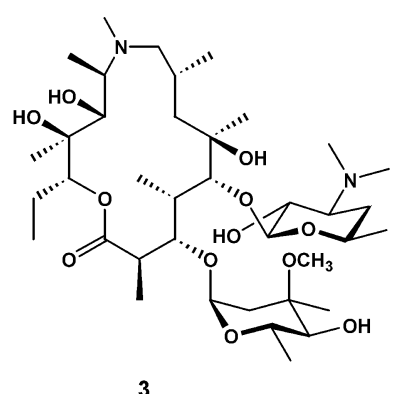

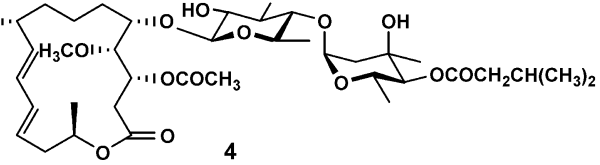

Fig. 1 Structures of clarithromycin $A$ (CLA, 1), erythromycin $A(E R Y, 2)$, azithromycin (AZM, 3), josamycin (4), roxythromycin (RXM, 5) and biotinylated-clarithromycin (6).

the ability of the protein to bind double-stranded DNA (dsDNA), as shown by gel shift assays. The binding of the recombinant $\mathrm{p} 8$ protein with double stranded DNA was also found to be interrupted by the addition of dechlorogriseofulvin which was screened by gel mobility shift assay from a natural product library.

\section{Experimental}

\section{Materials}

All materials used in this study are described in reference 10 .

\section{BLAST Search}

Homology search was performed with the peptide sequence "NSPAGISRELVDKLAAALE" against a human genome web site of National Center for Biotechnology Information (NCBI).

\section{Expression and Purification of PDGF-A (Platelet- derived Growth Factor A-chain)}

The PDGF-A fragment (amino acid 85-193) was obtained from a human leukocyte cDNA library. The primers used were: 5'-GAATTCAAGAGAAGCATCGAGGAAGCT-3' and $5^{\prime}$-CTCGAGCGTGTCCTCTTCCCGATAATC-3'. The

DNA fragment after PCR amplification was inserted into the EcoRI and XhoI sites of the pET28a vector (Novagen, Merck KGaA, Darmstadt, Germany). Escherichia coli strain BL21 (DE3) race+ was used as the host for heterologous gene expressions. After transforming with the expression construct, a single colony was used to inoculate $500 \mathrm{ml}$ of LB medium containing $50 \mu \mathrm{g} / \mathrm{ml}$ of kanamycin and chloramphenicol. After several hours of growth $30^{\circ} \mathrm{C}$ when the OD reached 0.7 heterologous gene expression was induced by adding IPTG (1.0 mM final) and incubated for an additional 3 hours. Cells were then harvested by centrifugation $\left(20,800 \mathrm{~g}\right.$ for 20 minutes at $\left.30^{\circ} \mathrm{C}\right)$. The pellet was suspended in $10 \mathrm{ml}$ of ice-cold binding buffer $(20 \mathrm{mM}$ sodium phosphate $\mathrm{pH} 7.4,0.5 \mathrm{M} \mathrm{NaCl}, 0.1 \mathrm{mM}$ leupeptin, $0.1 \mathrm{mM}$ pepstatin, $1.0 \mathrm{mM}$ phenylmethylsulfonylfluoride, $5.0 \mathrm{mM} \beta$-mercaptoethanol) and sonicated $20 \times 10$ seconds at $4^{\circ} \mathrm{C}$. The soluble protein fraction was collected and loaded onto a column $(5.0 \mathrm{ml}$ of Hi-trap-chelating-HP column, Amersham Biosciences AB, GE Healthcare, Uppsala, Sweden). The column was washed with $200 \mathrm{ml}$ of wash buffer $(20 \mathrm{mM}$ sodium phosphate $\mathrm{pH} 4.0,0.5 \mathrm{M}$ $\mathrm{NaCl}, 60 \mathrm{mM}$ imidazole) and the protein bound to the resin were eluted with an eluting buffer $(20 \mathrm{ml}, 20 \mathrm{mM}$ sodium phosphate $\mathrm{pH} 7.4,0.5 \mathrm{M} \mathrm{NaCl}, 1.0 \mathrm{M}$ imidazol) using a FPLC system (Akta Explorer, Amersham Biosciences AB). The eluted recombinant PDGF-A protein was used for SPR (surface plasmon resonance) experiment.

\section{Expression and Purification of p8 Protein}

The TG buffer contained the following reagents; $50 \mathrm{mM}$ Tris- $\mathrm{HCl}$ (pH 7.5), 10\% (v/v) glycerol, 0.01\% Nonidet-P40 and protease inhibitors of $1.0 \mathrm{mg} / \mathrm{ml}$ leupeptin and pepstatin, and $1.0 \mathrm{mM}$ phenylmethylsulfonyl fluoride (PMSF). His-tag binding buffer contained the following reagents; $20 \mathrm{mM} \mathrm{NaH} \mathrm{PO}_{4}, 0.5 \mathrm{M} \mathrm{NaCl}, 10 \mathrm{mM}$ imidazole, $10 \%(\mathrm{v} / \mathrm{v})$ glycerol, $\mathrm{pH}$ 7.5. His-tag elution buffer contained the following reagents; $20 \mathrm{mM} \mathrm{NaH} \mathrm{NO}_{4}, 0.5 \mathrm{M}$ $\mathrm{NaCl}, 500 \mathrm{mM}$ imidazole, $10 \%(\mathrm{v} / \mathrm{v})$ glycerol, $\mathrm{pH}$ 7.5. The P8 fragment was obtained from a human full-length EST clone, clone ID: CS0DI015YP05 (Invitrogen, Carlsbad, CA). pET28a vector (Novagen, Merck KGaA, Darmstadt, Germany) containing the entire P8 coding sequence was digested with $N d e \mathrm{I}$ and $\mathrm{XhoI}$. The primers used were: 5'-CATATGGCCACCTTCCCACCAGCAAC-3' and 5'CTCGAGTCAGCGCCGTGCC-3'. The p8 open reading frame (GenBank Accession No. AL545570) encoded a polypeptide of 82 residues with a molecular mass of 8.9 $\mathrm{kDa}$. E. coli BL21(DE3) pLysS was used as the host for heterologous gene expression. After transformation with the expression construct a single colony was used to inoculate $100 \mathrm{ml}$ of LB medium containing $1.0 \%$ glucose 
and $100 \mu \mathrm{g} / \mathrm{ml}$ ampicillin. The culture was grown overnight at $30^{\circ} \mathrm{C}$ and $100 \mathrm{ml}$ was used to inoculate 2.0 liters of SB medium containing $1.0 \%$ glucose. After 1 hour of growth at $30^{\circ} \mathrm{C}$ heterologous gene expression was induced by adding IPTG (1.0 mM final) and the culture was continued for a further 2 hours. Cells were then harvested by centrifugation $\left(15,000 \mathrm{~g}\right.$ for 10 minutes at $\left.4^{\circ} \mathrm{C}\right)$. The pellet was suspended in TG buffer, sonicated 10 times for 30 seconds and centrifuged for 20 minutes at $30,000 \mathrm{~g}$ at $4^{\circ} \mathrm{C}$. The supernatant was then mixed with $5.0 \mathrm{ml}$ of charged and washed His.Bind Resin (Novagen, Merck KGaA, Darmstadt, Germany). The column was washed with $100 \mathrm{ml}$ of TG buffer and proteins bound to the resin were eluted with Tris- $\mathrm{HCl}(\mathrm{pH} 7.5)$ containing $10 \%$ (v/v) glycerol and $100 \mathrm{mM}$ glutathione (reduced form). The eluted recombinant $\mathrm{P} 8$ protein was dialyzed against $\mathrm{TG}$ buffer. The molecular weight of the recombinant $\mathrm{p} 8$ was determined on a MALDI TOF MS to be $m / z 10906.03$ for $[\mathrm{M}+\mathrm{H}]^{+}$(theoretical value; $\mathrm{m} / \mathrm{z}$ 10905.74).

\section{Surface Plasmon Resonance (SPR)}

Binding of the recombinant $\mathrm{p} 8$ protein with biotinylatedCLA (6) was analyzed using a Biosensor BIAcore 3000 instrument (GE Healthcare Bio-Sciences AB, Uppsala, Sweden) with streptavidin research grade sensor chips. All buffers were filtered before use. Biotinylated-CLA (6) was immobilized on a SA (streptavidin) sensor chip by injecting a $20 \mu \mathrm{l}$ solution $(30 \mu \mathrm{g} / \mathrm{ml})$ in coupling HBS-EP buffer (0.01 M HEPES, pH 7.4, $0.15 \mathrm{M} \mathrm{NaCl}, 0.005 \%$ surfactant P20, $3.0 \mathrm{mM}$ EDTA plus $10 \%(\mathrm{v} / \mathrm{v})$ DMSO, $\mathrm{pH} 5.0)$ at a flow rate of $20 \mu \mathrm{l} /$ minute for 3 minutes. Binding analysis of human $\mathrm{p} 8$ protein was performed in running buffer (HBSEP buffer, pH 7.4) at a flow rate of $20 \mu \mathrm{l} /$ minute at $25^{\circ} \mathrm{C}$. Kinetic parameters were determined using the software BIA evaluation 3.1.

Binding of immobilized PDGF-A on a CM5 (carboxymethyl dexstran) sensor chip with biotinylatedCLA was also analyzed using BIAcore 3000 instrument described in ref. 10.

\section{Gel Mobility Shift Assay}

The gel mobility shift assay was carried out as described by Encinar et al. [11]. The binding mixture (a final volume $20 \mu \mathrm{l})$ of $25 \mathrm{mM}$ HEPES, $50 \mathrm{mM} \mathrm{NaCl}, 1.0 \mathrm{mM}$ DTT, $0.05 \%$ Nonidet P-40, $10 \%$ (v/v) glycerol, $20 \mathrm{mM}$ EDTA, $15 \%$ (v/v) DMSO (including compounds), $10 \mathrm{nM} 254 \mathrm{bp}$ DNA (amplified with M13 (-29) forward and M13 reverse primers from pBluescript II SK+), and 0 or $2.4 \mu \mathrm{M}$ of the P8 protein. Samples were run on a $1.0 \%$ agarose gel in $0.1 \mathrm{M}$ Tris acetate buffer $\mathrm{pH} 8.3$, containing $5 \mathrm{mM}$ EDTA at $50 \mathrm{~V}$ for 2 hours at $4^{\circ} \mathrm{C}$, and then the gel was stained with ethidium bromide.

For inhibitor screening from our natural product library, various concentrations of compounds $(0,0.6,1.2,2.4$ and $4.8 \mu \mathrm{M})$ were added in the binding mixture as above mentioned followed by incubation at $4{ }^{\circ} \mathrm{C}$ for 10 minutes. After addition of dsDNA $(0.1 \mu \mathrm{M})$, the gels were run on a $1.0 \%$ agarose gel in $0.1 \mathrm{M}$ Tris acetate buffer $\mathrm{pH} 8.3$, containing $5.0 \mathrm{mM}$ EDTA at $50 \mathrm{~V}$ for 2 hours at $4^{\circ} \mathrm{C}$, and then it was stained as described above.

\section{Results}

\section{Homology Search of Peptide Sequences}

The selected nucleotide sequence and its translation product (NSPAGISRELVDKLAAALE), obtained from T7 phage display in ref. 10 and above, were screened against the Swiss Prot protein database using the FASTA program [12]. Aligned score by ClustalW (ver 1.80) were 41 for human $\mathrm{p} 8$ protein (from 13 residues of the query sequence) to a portion of the human_p8 protein in the residues 58-70 of 82 amino acids (Fig. 2A). This is a dsDNA-binding protein found in the nucleus that responds to proapoptotic stimuli and promotes cell growth to counteract injury to the tissue. Human_p8 protein also contributes to the metastatic phenotype [9], although its function has not yet been fully elucidated. Aligned score by ClustalW (ver 1.80) was also obtained to be 31 for PDGF-A.

\section{Surface Plasmon Resonance (SPR) Analysis}

To confirm the binding of human $\mathrm{p} 8$ protein to the biotinylated-CLA (6) as a ligand, the dissociation constant was determined by using the sensor chip immobilized to the ligand in a BIAcore. Three different concentrations of the recombinant $\mathrm{p} 8$ protein $(2.0,4.0$ and $6.0 \mu \mathrm{M})$ were used for binding analysis. The ligand was immobilized on the streptavidin sensor chips, and then the protein solution was added. The dissociation constant $\left(\mathrm{K}_{\mathrm{D}}\right)$ was determined to be $5 \times 10^{-5} \mathrm{M}$ (Fig. 3). This confirms that biotinylated-CLA (6) interacts directly with the recombinant $\mathrm{p} 8$ protein, as suggested from our biopanning experiments.

The bindings of PDGF-A to the macrolide antibiotics were also performed by SPR analyses. The protein was immobilized on a carboxymethyl dextran matrix (CM5) sensor chip, and then three different concentrations of each macrolide antibiotic were used for binding analysis. The dissociation constants $\left(\mathrm{K}_{\mathrm{D}}\right)$ of the macrolides with the protein were determined to be less than $1 \times 10^{-3} \mathrm{M}$. Thus PDGF-A is not a binding protein for antibiotic macrolides. 

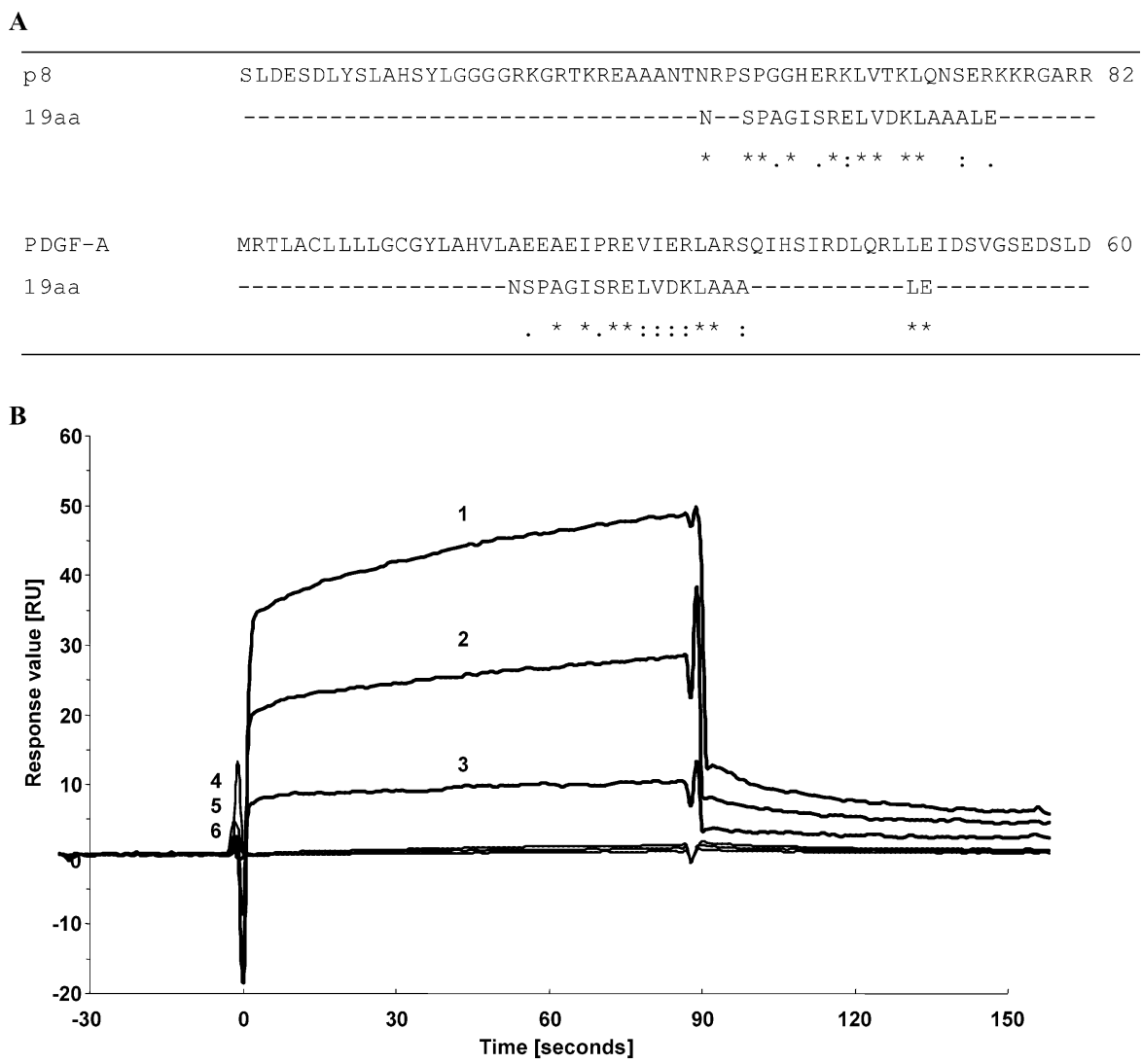

Fig. 2 Homology of human_p8 and PDGF-A with a displayed 19 amino acid sequence and BIAcore analysis of biotinylated-clarithromycin to human_p8 protein.

(A) Aligned scores by ClustalW (ver 1.80) were 41 for human_p8 protein and 31 for PDGF-A, respectively. (B) Binding of biotinylatedCLA (6) to the recombinant human_p8 protein was detected by surface plasmon resonance (SPR) signals (BIAcore, see Experimental Section), and is indicated in response units. Three different concentrations of the protein (curve 1: $6.0 \mu \mathrm{mol}$, curve 2: $4.0 \mu \mathrm{mol}$ and curve 3: $2.0 \mu \mathrm{mol})$ were injected over the immobilized biotinylated-CLA $(6,30 \mu \mathrm{g} / \mathrm{ml})$ on a streptavidin sensor chip for 3 minutes at $20 \mu \mathrm{l} / \mathrm{minute}$ and dissociated for 90 seconds at $20 \mu \mathrm{l} /$ minute. The background resulting from injection of running buffer alone was subtracted from the data before plotting. For the negative control, three different concentrations of BSA (curve 4: $6.0 \mu \mathrm{mol}$, curve 5: $4.0 \mu \mathrm{mol}$ and curve 6: $2.0 \mu \mathrm{mol}$ ) were injected over the immobilized biotinylated-CLA (6) on a streptavidin sensor chip in the same manner.

\section{Analysis of the Binding between Recombinant Human_p8 Protein with Several Macrolide Antibiotics} The DNA-binding properties of the recombinant $\mathrm{p} 8$ protein were analyzed. Fig. 4A shows the gel mobility shift assay of dsDNA ( 254 base pair) to the recombinant $\mathrm{p} 8$ protein. In the binding assay, dsDNA at $10 \mathrm{nM}$ (nucleotide) was added to $0 \sim 9.6 \mu \mathrm{M}$ of $\mathrm{p} 8$ protein (Fig. $4 \mathrm{~A}$, lanes $3 \sim 8$ ). The $\mathrm{p} 8$ protein bound to dsDNA was shifted in the gel (lanes $4 \sim 8$ ), whereas dsDNA with CLA or $1.5 \%$ DMSO as a solvent was not (lanes 2 and 3, respectively). BiotinylatedCLA (6), CLA (1), ERY (2) and AZM (3) interfered with the complex formation between $\mathrm{p} 8$ protein $(2.4 \mu \mathrm{M})$ and dsDNA (10 nM) (Fig. 4B). The inhibitions by biotinylatedCLA (6), CLA (1), ERY (2) and AZM (3) were observed at $2.4,1.2,2.4$ and $0.6 \mu \mathrm{M}$, respectively. However, JSM (4) and RXM (5) did not inhibit the binding of DNA to p8 protein.

\section{Screening of Gel Mobility Shift Assay}

Each solution of 85 compounds $(0,0.6,1.2,2.4$ and $4.8 \mu \mathrm{M}$ ) from our natural product library was added into p8-dsDNA gel mobility shift assay instead of macrolides. The interaction $\mathrm{p} 8$ and dsDNA was not interrupted by the addition of those solutions with one exception, dechlorogriseofulvin (7). When the solution of dechlorogriseofulvin was added in the gel mobility shift assay, the mobility of dsDNA was not observed. Thus the compound (7) inhibited the interaction of human_p8 protein and dsDNA. The direct interaction of $\mathrm{p} 8$ protein with dechlorogriseofulvin has not been obtained, because p8 protein immobilized on a CM5 chip did not respond for any ligand in SPR analysis. Since a biotinylateddechlorogriseofulvin was not available, the immobilized biotinylated-CLA was used as a ligand and $\mathrm{p} 8$ protein was used as an analyte. In the case of PDGF-A, the protein was 


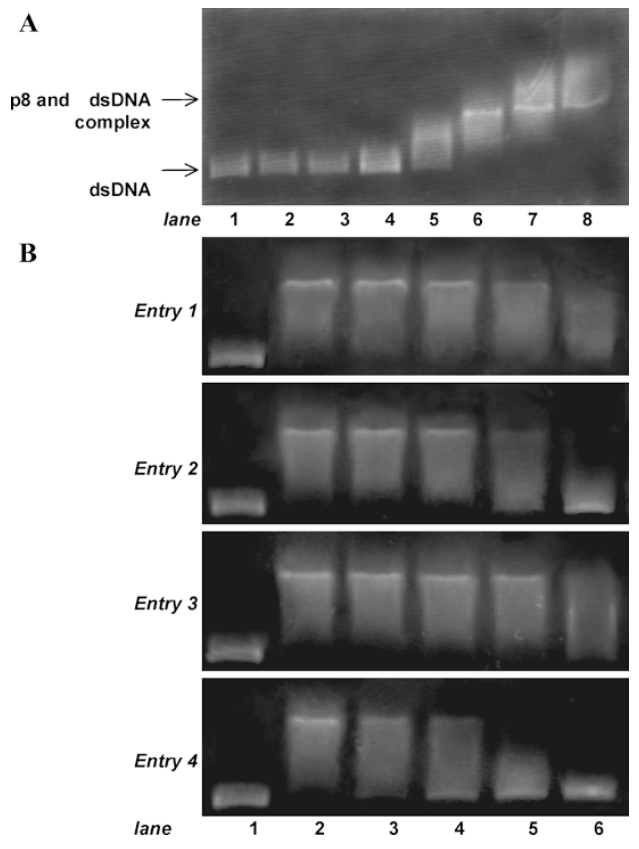

Fig. 3 Gel mobility shift analysis of the binding of the recombinant p8 protein to dsDNA.

Each sample in a final volume of $20 \mu \mathrm{l}$ was run on a $1.0 \%$ agarose gel at $50 \mathrm{~V}$ for 2 hours. A photograph of an ethidium bromide-stained gel is shown. A: Gel shift analysis of binding between the recombinant $\mathrm{p} 8$ protein and dsDNA. Synthetic dsDNA (10 nM, $254 \mathrm{bp}$ ) and recombinant p8 protein was mixed. Lanes 1 3 contained no protein; lanes $4 \sim 8$ were each mixed with a different concentration of protein $(0.6,1.2,2.4,4.8$ and $9.6 \mu \mathrm{M}$, respectively): lanes 2 8 contained $15 \%(\mathrm{v} / \mathrm{v}) \mathrm{DMSO}$ and lane 2 contained CLA $(\mathbf{1}, 1.0 \mu \mathrm{M})$. B: Gel shift analysis of binding between recombinant $\mathrm{p} 8$ protein, dsDNA and macrolides (biotinylated-CLA 6, CLA 1, ERY 2 and AZM 3 for entries 1 4, respectively). Synthetic dsDNA (10 nM, $254 \mathrm{bp})$, recombinant p8 protein $(0 \mu \mathrm{M}$ in lane 1 and $2.4 \mu \mathrm{M}$ in lanes 2 6, respectively) was mixed. Lanes 1 2 contained no macrolide, lanes 3 6 were each mixed with different concentrations of macrolide $(0.3,0.6,1.2$ and $2.4 \mu \mathrm{M}$, respectively).

immobilized on a CM5 sensor chip as ligand, thus CLA was able to use as an analyte.

\section{Conclusions}

We have used a phage display technique to screen for human proteins that specifically bind to clarithromycin. Affinity guided biopanning using biotinylatedclarithromycin selected a peptide composed of 19 amino acids displaying similarity to human_p8 protein. SPR experiments showed that the biotinylated-CLA (6) displays a good affinity for a recombinant human_p8 protein. Biotinylated-CLA (6), CLA (1), EMY (2) and AZM (3)

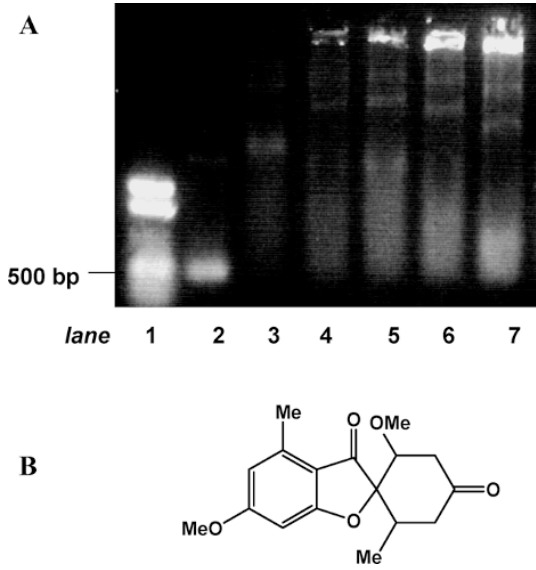

Fig. 4 Gel shift analysis of binding between recombinant p8 protein, dsDNA and griseofulvin.

A: Synthetic dsDNA $(10 \mathrm{nM}, 254 \mathrm{bp})$, the recombinant p8 protein $(0 \mu \mathrm{M}$ in lanes $1 \sim 2,2.4 \mu \mathrm{M}$ in lanes $3 \sim 7$, respectively) were mixed. Lanes $1 \sim 3$ contained no griseofulvin, lanes $4 \sim 7$ were each mixed with different concentrations of griseofulvin $(0.6,1.2$, 2.4 and $4.8 \mu \mathrm{M}$, respectively). B: Structure of dechlorogriseofulvin.

inhibited the DNA binding activity of the recombinant $\mathrm{p} 8$ protein, although RXM (5) and JSM (4) showed no effect. There could be other human proteins that specifically bind to macrolide antibiotics. Further biopanning with JSM (4), RXM (5) and/or their biotinylated derivative(s) could identify more macrolide-binding proteins.

Three of five antibiotic macrolides tested in the gel mobility shift assay interrupted the interaction of the recombinant human_p8 protein and dsDNA. The binding was also found to be interrupted by the addition of dechlorogriseofulvin which was screened by gel mobility shift assay from a natural product library. Thus, it can be expected that the biological function of human_p8 protein [12] may be explored by using antibiotic macrolides and/or dechlorogriseofulvin.

\section{References}

1. Morimoto S, Takahashi Y, Watanabe Y, Omura S. Chemical modification of erythromycins. I. Synthesis and antibacterial activity of 6-O-methylerythromycins A. J Antibiot 37: 187-189 (1984)

2. Schunzen F, Zarivach R, Harms J, Bachan A, Tocilj A, Albrecht R, Yonath A, Franceschi F. Structural basis for the interaction of antibiotics with the peptidyl transferase centre in eubacteria. Nature 413: 814-821 (2001) and references therein.

3. Leung WK, Graham DY. Clarithromycin for Helicobacter pylori infection. Expert Opin Pharmacother 1: 507-514 
(2000)

4. Jacks SS, Giguere S, Nguyen A. In vitro susceptibilities of Rhodococcus equi and other common equine pathogens to azithromycin, clarithromycin, and 20 other antimicrobials. Antimicrob Agents Chemother 47: 1742-1745 (2003)

5. Kurdowska A, Noble JM, Griffith DE. The effect of azithromycin and clarithromycin on ex vivo interleukin-8 (IL-8) release from whole blood and IL-8 production by human alveolar macrophages. J Antimicrob Chemother 47: 867-870 (2001)

6. Kikuchi T, Hagiwara K, Honda Y, Gomi K, Kobayashi T, Takahashi H, Tokue Y, Watanabe A, Nukiwa T. Clarithromycin suppresses lipopolysaccharide-induced interleukin- 8 production by human monocytes through AP-1 and NF-kappa B transcription factors. J Antimicrob Chemother 49: 745-755 (2002)

7. Sasaki M, Ito T, Kashima M, Fukui S, Izumiyama N, Watanabe A, Sano M, Fujiwara Y, Miura M. Erythromycin and clarithromycin modulation of growth factor-induced expression of heparanase mRNA on human lung cancer cells in vitro. Mediators Inflamm 10: 259-267 (2001)
8. Yatsunami J, Hayashi S. Fourteen-membered ring macrolides as anti-angiogenic compounds. Anticancer Res 21: 4253-4258 (2001)

9. Morris TC, Ranaghan L, Morrison J. Phase II trial of clarithromycin and pamidronate therapy in myeloma. Med Oncol 18: 79-84 (2001)

10. Morimura $\mathrm{T}$, Noda N, Kato N, Watanabe $\mathrm{T}$, Saitoh $\mathrm{T}$, Yamazaki T, Takata K, Aoki S, Ohta K, Ohshige M, Sakaguchi K, Sugawara F. Identification of antibiotic clarithromycin binding peptide displayed by $\mathrm{T} 7$ phage particles. J Antibiot 59: 625-632 (2006)

11. Casas-Finet JR, Kumar A, Morris G, Wilson SH, Karpel RL. Spectroscopic studies of the structural domains of mammalian DNA beta-polymerase. J Biol Chem 266: 19618-19625 (1991)

12. Encinar JA, Mallo GV, Mizyrycki C, Giono L, GonzalezRos JM, Rico M, Canepa E, Moreno S, Neira JL, Iovanna JL. Human p8 is a HMG-I/Y-like protein with DNA binding activity enhanced by phosphorylation. J Biol Chem 276: 2742-2751 (2001) 